\title{
Żyć w cieniu pytań. Antropologiczne przesłanie Expositio super Iob św. Tomasza z Akwinu*
}

\section{Life in the shadow of questions. Anthropological dimension of Expositio super Iob of St. Thomas Aquinas}

Słowa klucze: Tomasz z Akwinu; egzegeza średniowieczna; opatrzność; dysputy; cierpienie; szczęście.

Key words: Tomas Aquinas; medieval exegesis; providence; disputation; suffering, happiness.

Streszczenie. W bogatej aktywności komentatorskiej Tomasza z Akwinu od wielu lat uwagę badaczy zwraca egzegeza Księgi Hioba, wyróżniająca się zarówno stylem, jak i treścią od pozostałych komentarzy. Określany już w swym tytule jako komentarz ad litteram, nie skupia się jedynie na wątkach duchowych (podejmowanych przez Grzegorza Wielkiego w Moralia in Iob i przez Tomasza podzielanych), lecz na interpretacji tajemnicy Opatrzności Bożej, która przekłada się na szereg zagadnień metafizycznych (relacja Boga do świata, Jego znajomość poszczególnych jednostek) czy soteriologicznych o istotnym znaczeniu dla chrześcijańskiej wiary i samej teologii. Tomasz odczytuje tę biblijną księgę jako swoistą dysputę (disputatio), w której myślenie Hioba zostaje przeobrażone: od zmysłowego, przez racjonalne aż po uległe natchnieniu Bożemu. Zmiana dokonuje się na drodze stawiania pytań i prób, stanowiących słowa klucze i kryterium niniejszego artykułu. Tym samym Tomasz szkicuje niejako antropologię pisaną z perspektywy cierpienia, doświadczeń i prób, a z drugiej strony na tej kanwie przekazuje inspirujące myśli dla teologii rozumianej przecież w jego czasach jako sacra doctrina, w całej palecie zagadnień i kwestii dotyczących relacji człowieka z Bogiem (przecież w projekcie Tomaszowym teologia rozważa wszystko sub ratione Dei). Teologia sytuuje się w dynamizmie tego noszenia pytań i oświetlania ich mocą revelatio,

W artykule wykorzystano informacje zdobyte w ramach realizowanego grantu „Biblia i metafizyka. Hermeneutyka średniowiecznych komentarzy Tomasza z Akwinu do Corpus Paulinum" sfinansowanego ze środków Narodowego Centrum Nauki przyznanych na podstawie decyzji numer DEC-2012/04/M/HS1/00724. 
która odsłania cel ostateczny człowieka, ale czyni to wcielając niejako w egzystencję, w jej konkretne kształty.

\begin{abstract}
In the rich biblical activity of Thomas Aquinas, recently the attention of researchers is call by his exegesis of the Book of Job. This commentary distinguishes with his style and content from the other biblical work of Aquinas. Determined already in its title as commentary ad litteram, not only concentrates his attention to the moral themes (analyzed by the Gregory the Great in his Moralia in Iob and which Thomas shared and accept), but on interpretation of mystery of Providence of God, that initiates a range of metaphysical (like a relation of God to the world, his knowledge of individual beings etc.) or soteriological issues, which have a special importance for Christian faith and for theology. Thomas interprets a book of Job as some kind of dispute (disputatio), where the way of thinking of Job is transformed: from sensual through rational to this one which is open and docile to divine inspiration. The change is made on the way of questions and trials, which are the key of this paper. The perspective of debate and question, that Aquinas discover in the book of Job, is very useful and inspire the theology as sacra doctrina, with all his references to the questions of relationship between God and human being (because of Aquinas's project of theology that considers all things sub ratione Dei). Theology is situated in this dynamism of "bringing" questions and illuminating its by the light of revelatio, which manifest the final goal of man, but it is making this in clear existential dimension.
\end{abstract}

$\mathrm{K}^{\mathrm{s}}$ sięga Hioba należy do jednej z najbardziej popularnych w średniowieczu ksiąg biblijnych. Dotyczy to nie tylko literatury, ale także malarstwa, które $z$ upodobaniem powracało szczególnie do sceny mizerii i ubóstwa Hioba, będącego konsekwencją „próby”, której został poddany za Bożym przyzwoleniem $^{1}$. Średniowiecznych artystów zadziwiała nietypowa cierpliwość Hioba, ale również ciekawiło pytanie o bona fortuna czy o naturę „zrządzeń losu”, które przebijało z jego historii.

Teologiczne odpowiedzi na historię Hioba udzielane przez scholastycznych mistrzów odwoływały się do pogłębionego studium filozoficzno-teologicznego opatrzności, uwalniając przy tym szereg ważnych kwestii metafizycznych (Bóg i świat, ich wzajemna relacja), moralnych (sens cierpienia) czy soteriologicznych (istota zbawienia). A przy tym jego sytuacja stanowiła dla średniowiecznych teologów instrygujący przyczynek do rozważań nad conditio humana, a zwłaszcza jaki jest sens prób i doświadczeń spotykających człowieka sprawiedliwego i prawego.

Ale Tomasz z Akwinu obok tych ważnych i doniosłych tematów widział w historii Hioba coś jeszcze, co przebija z kart jego komentarza: pełne dosto-

1 J. Le Goff, Człowiek średniowiecza, Oficyna Wydawnicza Volumen, Warszawa-Gdańsk 1996. 
jeństwa życie z ciężarem pytania. Pytania, od którego Hiob się całkowicie nie uwalnia. Dlatego jego casus można w jakiejś mierze uznać za paradygmatyczny dla tego, czym jest teologia jako dyscyplina stawiająca najszersze pytania o rzeczywistość na podstawie otrzymanego w darze światła Objawienia.

Święty Tomasz, jak ciekawie podkreślał w jednym ze swoich esejów Hans Urs von Balthasar ${ }^{2}$, należy do filozofów „przyczyn wtórnych”. Wynika to z faktu, o którym pisał również R. Guardini ${ }^{3}$, że świat scholastyków (i ogólnie średniowiecza) doświadcza w stosunku do starożytnej kosmowizji znacznego poszerzenia. To nie jest świat zamknięty w immanentyzmie olimpijskich bogów, lecz ten, który odkrywa wymiar transcendentny, a to to dokonuje się dzięki biblijnej koncepcji stworzenia. Oznacza ona podjęcie zagadnienie rozumienia "natury ludzkiej”, która nie jest monadyczna, lecz dynamiczna, bo ukształtowana na kanwie relacyjności, zarówno w wymiarze wertykalnym, jak i horyzontalnym ${ }^{4}$. Dlatego pytanie o człowieczeństwo zostaje zadane przez Tomasza nie tyle samemu człowiekowi, ile Bogu, dzięki któremu człowiek odkrywa pełne wymiary autentyzmu swego losu $\mathrm{s}^{5}$. Natura relacji Boga do świata stoi u podstaw również jego komentarza do Księgi Hioba. Zdaniem św. Tomasza zadawanie pytań Bogu jest dobrym tropem w dyskursie o człowieku. Prowadzenie dysputy z Bogiem o tym, co najważniejsze może bowiem znacząco pomóc w odrzuceniu tego, co ma jedynie pozór racjonalności (a tak Akwinata kwalifikuje wypowiedzi przyjaciół Hioba) $)^{6}$.

W niniejszym artykule nie skupimy się wyłącznie na zasadniczym wątku tematycznym Tomaszowego komentarza do Hioba, który wiąże się z tajemnicą opatrzności Bożej, kwestią poznawalności przez Boga zdarzeń indywidualnych i samych jednostek (a więc naturę wiedzy Boga). Nie zapominając o temacie głównym, pójdziemy dalej drogą wytyczoną przez M. Manzanedo ${ }^{7}$, D. Char-

2 Por. H. Urs von Balthasar, Patristik, Scholastik und Wir, Teologie der Zeit 2 (1939), s. $65-104$.

3 Por. R. Guardini, El ocaso de la edad moderna, w: Obras, vol. 1, Ediciones Cristiandad, Madrid 1981.

4 Por. M. Kostelecky, Thomas Aquinas's «Summa contra gentiles»: a mirror of human nature, Peeters, Lovain 2013.

5 Śledząc wielkie dane tradycji, w tym także obejmującej teologię św. Tomasza z Akwinu, zwracał na to uwagę w obszernej i wnikliwej monografii R.J. Woźniak, Różnica i tajemnica. Objawienie jako teologiczne źródło ludzkiej sobości, W drodze, Poznań 2012.

6 Por. M. Levering, Ordering Wisdom. Aquinas, the Old Testament and Sacra Doctrina, w: R. Hutter, M. Levering, Ressourcement Thomism. Sacred Doctrine, the Sacraments and the Moral Life, Catholic University of America Press, Washington 2010, s. 87.

7 M. Manzanedo, La antropología teológica en el comentario tomista al libro de Job, Angelicum 2 (1987), s. 301-331. 
donnens ${ }^{8}$ czy I.-J. Saranyanę ${ }^{9}$, którzy w swoich ciekawych publikacjach wydobywają z Tomaszowego komentarza ponadczasowe topiki antropologiczne: dlaczego cierpią dobrzy i triumfują źli? Jaki model człowieczeństwa ucieleśnia Hiob? Jakie pytania stawia? Co wnosi jego historia do refleksji nad człowiekiem i jego egzystencją?

Naszym punktem wyjścia i kryterium odczytania komentarza Tomaszowego będzie pryzmat dwóch istotnych terminów: „pytania” i „próby”. Z jednej strony postaramy się, śledząc rozumowanie Akwinaty, zastanowić nad znaczeniem prób i doświadczeń w życiu człowieka, szkicując niejako antropologię pisaną z perspektywy cierpienia, a z drugiej na tej kanwie odkryć inspirujące myśli dla teologii jako sacra doctrina, w całej palecie zagadnień i kwestii dotyczących relacji człowieka z Bogiem (przecież w projekcie Tomaszowym teologia rozważa wszystko sub ratione Dei).

\section{Aspekty formalne komentarza}

Komentarze średniowieczne, a te autorstwa Akwinaty są tego dobitnym przykładem, nie są tylko eksploracją sensu tekstów, ale poszukiwaniem odpowiedzi na kwestie dogmatyczne i moralne, na wyciągnięcie z nich elementów służących systematyzacji teologicznej i filozoficznej. Warto pamiętać ponadto, że każdy z komentarzy Akwinaty ma swoją literacką fizjonomię, swój własny sty $1^{10}$. Nie tylko $\mathrm{z}$ tego powodu, że powstają w różnych okresach życia św. Tomasza: wystarczy porównać styl młodzieńczego komentarza do Izajasza, do Listów św. Pawła czy interesującej nas Księgi Hioba. Ma znaczenie, czy tekst jest reportatio, czy jest czystym zapisem notatek jego studentów (jak w przypadku wyjaśniania psalmów), czy był przejrzany przez św. Tomasza (jak w przypadku komentarza do Listu do Rzymian), bo przecież wiadomo, że w średniowiecznym reportatio chodziło nie tyle o stenopisanie, co było dziedzictwem starożytnych technik, lecz o całościowe ujęcie argumentu mistrza. W przypadku expositio do Hioba mamy do czynienia $\mathrm{z}$ innym komentarzem, odmiennym od pozostałych również w swej formie literackiej: Tomasz chce śledzić wywody

8 D. Chardonnens, L'homme sous le regard de la Providence, J. Vrin, Paris 1997.

9 J.-I. Saranyana, ¿Por qué sufren los buenos y triunfan los malos?: comentario literal de Tomás de Aquino al Libro de Job (capítulos 1-3), Servicio de Publicaciones de la Universidad de Navarra, Pamplona 2010.

10 Por. M. Mróz, P. Roszak, Perfectus secundum intellectum et affectum. Ideał egzegety i jego pracy komentatorskiej wg Tomasza z Akwinu, Teologia i Człowiek 10 (2007), s. 113-130 . 
Hioba, nie dokonując tak wielu divisio textus jak w innych komentarzach, które mogłyby wstrzymywać wartki ciąg argumentacyjny, głęboko rozwija metafory, wprowadza częste „noty”. To istotna opcja metologiczna na rzecz jednolitości interpretacyjnej.

Komentarz do księgi Hioba posiada w sobie najmniej danych chronologicznych, które pozwoliłyby na jego umiejscowienie i dokładne określenie czasu powstania ${ }^{11}$. Wśród badaczy jedni, jak Mandonnet i Glorieux, wskazywali jako czas powstania expositio do Hioba drugą regencję paryską Tomasza (1269-1272), podczas, gdy inni, idąc za Ptolemeuszem z Lukki, opowiadali się za pierwszym pobytem Akwinaty we Włoszech (1261-1265). W myśl tej ostatniej teorii komentarz do Hioba byłby owocem nauczania Tomasza dla współbraci dominikanów w Orvieto. Wbrew wcześniejszym opiniom, które rolę Tomasza jako lector Curiae w Orvieto widziały w prowadzeniu wykładów dla papieskiej kurii, najnowsze badania pokazują, że chodziło nade wszystko o pracę formacyjną dla tych braci dominikanów, którzy nie przeszli kształcenia $\mathrm{w}$ ramach studium generale czy provinciale ${ }^{12}$. W ten sposób komentarz do Hioba powstawałby w tej samej epoce co trzecia księga Summa contra gentiles i podejmowałby ten sam temat centralny w obu dziełach: naturę opatrzności Bożej. Wydawcy komentarza z Leoniny (t. 26), w praefatio sklaniają się ku tej właśnie opcji, przyjmując włoskie Orvieto za miejsce powstania komentarza ${ }^{13}$.

Tomasz w prologu swego komentarza przywołuje autorytet św. Grzegorza Wielkiego i jego Moralia in Iob, zaznaczając jednak, że jego odczytanie Hioba nie będzie miało charakteru moralnego, lecz literalne, ad litteram, które w hermeneutyce biblijnej Akwinaty jest fundamentem teologicznej procedury ${ }^{14}$. Jak pokazała Beryl Smalley, zestawiając ze sobą wcześniejsze komentarze do Hioba

11 A, Colunga, El comentario de santo Tomas sobre Job, Ciencia Tomista 25 (1971), s. $45-50$.

12 W określeniu lector curiae chodziło o geograficzne określenie: termin ten wskazywał na lektora wykładającego w konwencie, który znajdował się w miejscowości, gdzie rezydowała Kuria. Tomasz więc miał w Orvieto wykłady - jak byśmy dziś określili - z zakresu teologii moralnej pastoralnej, które miały przygotować przyszłych kaznodziejów i spowiedników dominikańskich - szerzej na ten temat por. E. Panella, Il lector romanae curiae nelle cronache conventuali domenicane del XIII-XIV secolo, Civicima 5 (1992), s. 130-139.

13 Por. G. Emery, Breve catalogo de las obras de Santo Tomas, w: J.-P. Torrell, Iniciación a Tomas de Aquino: su persona y su obra, Eunsa, Pamplona 2003, s. 362.

14 I. Colosio, Florilegio di S. Tommaso al libro di Giobbe, Ascética y Mística 12 (1967), s. $566-572$. 
Wiktorynów, Hugona de St. Caro, Alberta Wielkiego, Tomasz wyróżnia się od wcześniejszych ujęć zdecydowanym naciskiem na wykład literalny ${ }^{15}$.

Tematyka komentarza dotyczy zwierzchności i niezmienności wyroków Bożych, spod których nie są wyjęte także ludzkie sprawy - cierpienie niewinnych nie zależy całkowicie od złośliwości złych duchów, lecz podlega boskiej mądrości. O ile auctoritas św. Grzegorza nie podlega wątpliwości (choć jego intepretacja jest przytoczona dopiero na końcu prologu Tomaszowego), o tyle komentarz jest wyraźną - choć pośrednią - polemiką z takim odczytaniem Księgi Hioba, którą zaproponował Mojżesz Majmonides, dla którego, inaczej niż dla Tomasza ${ }^{16}$, postać Hioba nie jest historyczna, lecz stanowi fikcję literacką. Jednak zasadnicza różnica obu interpretacji, jak zaznacza Leo Elders ${ }^{17}$, polega na postrzeganiu zakresu opatrzności Bożej, której wedle żydowskiego filozofa i egzegety, nie podlega wszystko, co dzieje się na świecie. Dla Tomasza tematem nie jest odmienna logika projektów Bożego i ludzkiego, jak dla Majmonidesa, lecz przekonanie, że życie człowieka jest kierowane przez Boga, który chce ukazać cnoty Hioba.

\section{Teologiczny background sprawy Hioba: natura relacji Boga do świata}

Aby w pełni zrozumieć szeroki zakres spraw i tematów, które podejmuje Tomaszowy komentarz do Hioba, trzeba zwrócić uwagę na leżące u jego podstaw metafizyczne rozumienie relacji Boga do świata i wynikające $\mathrm{z}$ tego postrzeganie natury Opatrzności Bożej ${ }^{18}$. Wpisując się w nurt tradycyjnego nauczania

15 Warto pamiętać, że lektura moralna komentarzy dominowała w hermeneutyce monastycznej w średniowieczu i taką rolę przypisywała komentarzom biblijnym. Mendykanci od początku starają się zachować równowagę między odczytanie duchowym (moralnym) a stricte teologicznym (właściwym nowej teologii) - por. B. Smalley, The Study of the Bible in the Middle Age, University of Notre Dame Press, Notre Dame ${ }^{3} 1978$, s. 264nn.

16 Choć Tomasz przyjmuje historyczność Hioba, to jednak w toku komentarza precyzuje, że fakt jego historyczności nie wprowadza rozbieżności co do interpretacji samej księgi i jej przesłania, gdyż Hiob jest uosobieniem człowieka każdej epoki, który żyje cnotliwie. Por. Mary L. O'Hara, C.S.J., Truth in Spirit and Letter: Gregory the Great, Thomas Aquinas, and Maimonides on the Book of Job, w: R. Elder, From Cloister to Classroom: Monastic and Scholastic Approaches to Truth, Cistertian Publications, Kalamazoo 1986, s. 59.

17 Por. L. Elders, El Comentario de Sto. Tomás de Aquino sobre el Libro de Job, w: idem, Hombre, Naturaleza y Cultura, EDUCA, Buenos Aires 1998, s. 82nn.

18 Por. M.D. Yaffe, Providence in Medieval Aristotelism: Moses Maimonides and Thomas Aquinas on the Book of Job, Hebrew Studies 20-21 (1979-1980), s. 62-74. 
Kościoła, sięgającego św. Augustyna, a docierającego do Akwinaty przez Piotra Lombarda, św. Tomasz zauważa, że stworzenie może być rozważane również jako „relacja” Boga do tego wszystkiego, co Nim nie jest ${ }^{19}$. Odrzucając neoplatońskie pokusy wypływające $\mathrm{z}$ emanacyjno-panteistycznej wizji świata, Tomasz obstaje przy rozumieniu świata jako posiadającego własne istnienie, ale nie w sensie późniejszej monady, lecz pozostającego w sieci dynamicznych i życiodajnych relacji z Stwórcą. Relacja ta nie zmienia niczego w Bogu, ale świat, by móc istnieć potrzebuje takiej relacji ze Stwórcą, która podtrzymuje go w swoim istnieniu (creatio continua). W myśli Tomaszowej odchodzi się od partycypacji jako planu formalnego dla uchwycenia tajemnicy stworzenia na rzecz schematu „skutek-przyczyna”, dogłębnie relacyjnej. Unika się w ten sposób postrzegania stworzenia jako Bożego wyjścia z siebie w duchu autoalienacji czy utraty mocy (konsekwencja neoplatońskiej emanacji rozumianej radykalnie) i optuje tym samym za językiem mówiącym raczej o „produkcji” (generatio), który widzi stworzenie jako coś co staje „wobec Boga” (coram Deo $)^{20}$. Tym samym afirmuje się pozytywną potencjalność bytu stworzonego wobec Boga, jego samoposiadanie. Tomasz proponuje więc wizję kosmosu uporządkowanego, ale nie będącego jedynie degradacją bytu (jak w niektórych odmianach emanatyzmu). Dlatego to, co jednostkowe, ma wartość, jest cenne i obdarzone własną godnością ${ }^{21}$.

Moc Boga będącego pierwszą przyczyną rozciąga się na wszystko, co od Niego inne, podobnie jak wiedza Boga, która dosięga nie tylko tego, co ogólne, ale i szczegółowe (konkretnych rzeczy materialnych) ${ }^{22}$. Bóg poznaje także to, co niedoskonałe, ale przez pryzmat tego, co doskonałe ${ }^{23}$. A jeśli Bóg poznaje to, co niedoskonałe via doskonałe, to oznacza w gruncie rzeczy, że poznaje przez

19 Por. P. Roszak, Creación como relatio, assimilatio y processio. En torno a la exégesis de santo Tomás de Aquino al Gen 1,1-2,3, Biblica et Patristica Thoruniensia 4 (2011), s. 169-184 .

20 Por. M. Levering, Biblical Thomism and the Doctrine of Providence, American Catholic Philosophical Quarterly 3 (2009), s. 339-362.

21 Por. H. Urs von Balthasar, Patristik, Scholastik und Wir, s. 102. W konsekwencji tego „Zwrotu scholastycznego", zauważa szwajcarski teolog, łaska przestaje oznaczać substancję pneumatyczną, jak to było w patrystyce, stając się modyfikacją substancji naturalnej, jej accidens - od tej chwili partycypacja i zjednoczenie (unio) mogą być rozumiane jako doskonałość i ukoronowanie „naturalności” natury. To istotne również dla zrozumienia Tomaszowego odczytania przesłania Księgi Hioba.

22 Por. S. Th., I, q. 14, a. 6: „Manifestum est autem quod per actum perfectum cognosci possunt actus imperfecti non solum in communi, sed etiam propria cognition".

23 J.M. Garrigues, Bóg, w którym nie ma idei zła, W drodze, Poznań 1996. 
samego siebie ${ }^{24}$. Ta niebezpośredniość boskiego poznania nie oznacza jednak gorszego czy niedoskonałego poznania, a wręcz odwrotnie, bardziej jeszcze doskonalsze, bo u samego źródła bytów ${ }^{25}$. Tajemnica opatrzności, rządów Boga nad światem jaśnieje na kanwie tak zarysowanej wizji relacji Boga ze światem, który Bóg poznaje, chce i kocha ${ }^{26}$. Historia Hioba zdaje się na pierwszy rzut oka chwiać tym światem w posadach, burzyć metafizyczną harmonię. Ale Tomasza interesuje nie tyle pytanie o opatrzność naturalną (nad bytami nieożywiony$\mathrm{mi}$ ), co sięgającą w sprawy człowieka ${ }^{27}$. Dlaczego dobrych spotkają nieraz złe rzeczy, a złych niejednokrotnie dobre?

Dlatego trzy pierwsze rozdziały komentarza są niejako przygotowaniem do rozważania najważniejszych kwestii, pełniąc rolę milczących założeń. Opisywane w Księdze Hioba scena w niebie czy dialog z szatanem, pokazują wielkie znaczenie, jakie dla Boga (ale i dla człowieka) ma przykład świętych i sprawiedliwych: znoszenie przez nich przeciwności umacnia w cnocie innych. Bóg pragnie, aby sprawiedliwość świętych była widoczna, nieraz w sytuacji konstrastu z doczesną niepomyślnością. Uwidacznia się tu prymat innego porządku odniesień niż tylko ludzka fortuna. Choć Bóg pozwala na doświadczanie Hioba, to rozmowa z szatanem obrazuje, że zakres jego szkód ma swój limit, nie jest nieskończony, taki jaki on by chciał. Po drugie, to nie Bóg nakazuje zesłanie przeciwności na Hioba, ale p o z w a l a na ich dokonanie. Nie jest więc to działanie Boga „ze względu na zło”, co dla Tomasza bardzo istotne, ale na dobro: by ukazać przykład sprawiedliwości, która często jest kwestionowana przez kalumnie niesprawiedliwych.

\section{3. Życie sub interrogatione: po co Hiob stawia Bogu pytania?}

Formułowanie pytań stanowiło rdzeń dydaktyki scholastycznej. Ogniskowało najważniejsze aporie, które odważnie formułowano, wychodząc z przekonania,

24 Tomasz określa relację między Bogiem a światem nie jako „realną”, lecz wedle rozumu (secundum rationem). Jak wykazuje ciekawe stadium McWorthera, jest to doskonalsza relacja (wbrew krytyce W.L. Craiga podnoszonej przeciw Tomaszowi) niż realna - por. M. McWorther, Aquinas on God's relation to the World, New Blackfriars 1049 (2013), s. 3-19.

25 S. Th., I, q. 14, a. 6, ad 1: „Deus non solum cognoscit res esse in seipso; sed per id quod in seipso continet res, cognoscit eas in propria natura; et tanto perfectius, quanto perfectius est unumquodque in ipso".

26 Por. H. Goris, Free Creatures of an Eternal God. Thomas Aquinas on God's Infallible Foreknowledge and Irresistible Will, Peeters, Louvain 1996.

27 Por. R. W. Nutt, Providence, Wisdom, and the Justice of Job's Afflictions: Considerations from Aquinas' Literal Exposition on Job, Heythrop Journal 1 (2011), s. 1-23. 
sięgającego św. Ambrożego, że „każda prawda, przez kogokolwiek nie zostałaby wypowiedziana, pochodzi od Ducha Świętego". Umiejętność ich stawiania to siła nośna teologicznego zamysłu. Dlatego formułowanie pytań przez Hioba rodzi prawomocne skojarzenia $z$ uprawianiem teologii i skupienie na nich uwagi - jak czyni Tomasz w swoim komentarzu - może przynieść wiele pożytku również teologicznym refleksjom. Teologia przecież to swoiste „myślenie z Bogiem", myślenie w nadwyżce sensu, który został podarowany i przez to sacra doctrina, jak w średniowieczu nazywano teologię, to nieustanne odnawianie znaczeń. W ujęciu Akwinaty człowiek jest obrazem Boga, nie tylko ze względu na swoje istnienie, ale ponieważ myśli: „w umyśle człowieka znajduje się podobieństwo do Boga na sposób obrazu ${ }^{28}$. R. Woźniak, rozwijając tę myśl, zauważa że „myślenie i rozumność ujmowane są przez Tomasza w duchu tradycji, jako przestrzenie podobieństwa, w których odzwierciela się, staje się widzialna boska genealogia człowieka oraz - co istotne - jego ostateczne przeznaczenie" 29 .

Hiob również stawia pytania - ostre jak jego sytuacja egzystencjalna. Są to jednak pytania nastawione na wiedzę, a nie na akrobatykę słowną w duchu pooświeceniowej teodycei ${ }^{30}$. Tomasz bilista czyta Księgę Hioba, nie rezygnując jednak z bycia filozofem i dlatego nie tyle „łagodzi” dyskurs Hioba, ile stara się wydobyć z niego cenną prawdę widoczną dopiero w łasce i Krzyżu Chrystusa: że cierpienie zostaje dopuszczone, napisze kilka lat później, już w Sumie teologii, aby człowiek lepiej poznał samego siebie oraz aby inni mogli lepiej nas zrozumieć.

Dla Tomasza jednak najistotniejsze jest już samo zabranie przez Hioba głosu po okresie ciszy: decyduje się przerwać milczenie, aby prowadzić disputatio z Bogiem. Ale czy w ogóle wypada człowiekowi prowadzić tego rodzaju dykurs? Odpowiedzią Tomasza jest imperatyw, aby nie milczeć, gdy w grę wchodzi prawda - ta bowiem nie zmienia się w zależności od tego, kto ją wypowiada i dlatego jedyną troską dyskutującego jest opowiadanie się po stronie prawdy:

Wydawać by się mogło, że dysputa między Bogiem a człowiekiem jest niewłaściwa z powodu wzniosłości, którą Bóg góruje nad człowiekiem; lecz trzeba pamiętać, że

28 S. Th., I, q. 93, a. 6c.

29 R. Woźniak, Różnica i tajemnica. Objawienie jako teologiczne źródło ludzkiej sobości, W drodze, Poznań 2012, s. 409.

30 In Iob., cap. 13: „Homo enim per decursum praesentis vitae paulatim consumitur, et praecipue cum est infirmitati subiectus sicut erat Iob; tacens autem consumitur qui sic praesentem vitam decurrit quod tamen suae sapientiae per doctrinam nullum vestigium relinquit: ne ergo Iob hoc pateretur, disposuit non tacere de veritate ut consumptus corpore post mortem viveret in sua doctrina". 
wzgląd na osoby nie zmienia prawdy, stąd gdy ktoś wypowiada prawdę, nie może być zwyciężony bez względu na to, kogo będzie miał za adwersarza [w dyskusji] ${ }^{31}$.

Pytania Hioba pokazują człowieka w kryzysie, którego słowa - często nawet sprzeczne w sobie - są możliwe do zrozumienia dopiero wówczas, gdy uwzględni się różne sposoby, w jakie wyraża Hiob swój stan ducha. Św. Tomasz wyróżnia trzy takie sposoby, które odsłaniają jednocześnie, jak ewoluuje, jakie etapy przechodzi myślenie Hioba, myślenie właściwe ludzkiej naturze doświadczającej głębokiego kryzysu. W pierwszym pozwala się prowadzić zmysłowym skutkom sytuacji, $\mathrm{w}$ drugim dyskuje racjonalnie przeciwko swoim przyjaciołom, natomiast końcowe mowy Hioba to wypowiedzi, w których staje się podatny na Boże natchnienie ${ }^{32}$, które ujawnia się nie tyle w zewnętrznym słowie, ile na drodze sumienia. Ta trójetapowość obrazuje drogę człowieka sprawiedliwego, który od doświadczeń zmysłowych, przez wysiłek racjonalny wsparty łaską Bożą, dochodzi do całkowitej conversio ad Deum. W Hiobie dyskutującym z Bogiem zachodzi przemiana, której czytelnik nie może ignorować: a ono dokonuje się $w$ czasie tego dialogu. Nie chodzi o tanie chwyty sofistów, ale o ukształtowanego ducha, który w ogniu pytań ustawia najlepszy kąt widzenia prawdy.

\subsection{Sztuka dobrych pytań: ordinata interrogatio Hioba}

Tomasz jest świadom wielkiej roli „pytania” w procesie dochodzenia do prawdy, ale nie jakiegokolwiek, lecz takiego, które jest „uporządkowane”, gdyż tym samym gwarantuje dostęp do wiedzy ${ }^{33}$. Polega ona na przechodzeniu od zasad wszystkim znanym i oczywistych do „własnych”.

31 In Iob., cap. 13: „Videbatur autem disputatio hominis ad Deum esse indebita propter excellentiam qua Deus hominem excellit; sed considerandum est quod veritas ex diversitate personarum non variatur, unde cum aliquis veritatem loquitur vinci non potest cum quocumque disputet” (tłum. wł. ) .

32 In Iob., cap. 39: „Iob tripliciter in hoc libro invenitur fuisse locutus: primo quidem quasi repraesentans affectum sensualitatis in prima conquestione cum dixit pereat dies, secundo exprimens deliberationem rationis humanae dum contra amicos disputaret, tertio secundum inspirationem divinam dum ex persona domini verba induxit; et quia humana ratio dirigi debet secundum inspirationem divinam, post verba domini, verba quae secundum rationem humanam dixerat reprehendit".

33 S. Th., I, q. 84 a. 3 ad 3: "Ad tertium dicendum quod ordinata interrogatio procedit ex principiis communibus per se notis, ad propria. Per talem autem processum scientia causatur in anima addiscentis". Szerzej o charakterze dydaktyki Tomaszowej D. Rohling, 
Komentarz do Hioba ukazuje pewien wzór dochodzenia do mądrości i przylgnięcia do prawdy, który znamienne określa jako inventio veritatis per disputationem, a przez to stanowi także ciekawe wskazówki dla teologii. O przeszkodach i manowcach źle uprawionej dysputy mówi Akwinata w szóstym rozdziale swego expositio litteralis do Księgi Hioba.

Dzięki prowadzeniu ciągłych dysput jaśnieje prawda; stąd dodaje nakłoń ucha, to znaczy posłuchaj, $i$ zobacz, to znaczy zastanów się, czy kłamię: to jest pierwsza przeszkoda w dochodzeniu do prawdy na drodze dysputy, gdy ktoś nie chce słyszeć argumentów, które podnosi przeciwnik. Drugą przeszkodą jest odpowiadanie na to, co się usłyszało w sposób głośny i obrażający [...] Trzecia przeszkoda pojawia się, gdy ktoś w dyspucie nie chce dojść do prawdy, lecz do zwycięstwa i chwały, jak to ma miejsce w dysputach adwokackich i sofistycznych [...]. Hiob zamierzał bronić i udowodnić prawdę ludzkich i boskich spraw ${ }^{34}$.

Wszystkie trzy przeszkody - brak chęci słuchania argumentów przeciwnika, głośna i nieproporcjonalna odpowiedź oraz chęć wygrania starcia intelektualnego, a nie dojścia do prawdy - dotyczą nie tylko dyskursów opisywanych w Księdze Hioba, ale trudno oprzeć się wrażeniu, biorąc pod uwagę zapewne różne doświadczenia uniwersyteckie Tomasza, że wiele mogą powiedzieć również o tym jak nie uprawiać dysputy w teologii. Tomasz dostrzega w Hiobie mistrza teologicznej dysputy, który właśnie w ten sposób - Iob procedit more disputatoris powie Akwinata - prowadzi swoją obronę: najpierw podważa sensowność i wykazuje fałsz rozumowania swoich przyjaciół, aby następnie w sposób pozytywny przedstawić to, co odczuwa jako prawdziwe ${ }^{35}$.

Tomasza zadziwia to, że Hiob mówi o swoim życiu sub interrogatione: przy czym owa interrogatio nie dotyczy jedynie pytania jako formy wypowiedzi, ale

Omne scibile est discibile. Eine Untersuchung zur Struktur und Genese des Lehrens und Lernens bei Thomas von Aquin, Aschendorff Verlag, Münster 2012.

34 In Iob, cap. 6: „ut ex mutua disputatione veritas elucescat; unde subdit praebete aurem, idest auscultate, et videte, idest considerate, an mentiar: hoc est enim primum impedimentum veritatis inveniendae per disputationem, cum aliquis ea quae ab adversario dicuntur audire non vult. Secundum impedimentum est cum ad audita clamose et contumeliose respondet, $[\ldots]$ Tertium impedimentum est cum aliquis in disputatione non intendit ad veritatem sed ad victoriam et gloriam, ut accidit in disputationibus litigiosis et sophisticis: [...]: intendebat enim et circa divina et circa humana defendere et probare veritatem" (tłum. własne).

35 In Iob, cap. 6: „Considerandum est autem quod Iob, cui a principio sufficit falsam opinionem refellere et postmodum aperit quid ipse de veritate sentiat”. 
jego zakorzenienia w pamięci i adekwatnej hermeneutyki ${ }^{36}$. To sonda wpuszczona w doświadczenie dziejów, które ukazuje najgłębsze i najważniejsze Boże ślady w ludzkiej historii. Hiob wyraża siebie przez pytanie - z delikatnością właściwą pokornemu poszukiwaniu, otwartemu na możliwość błędu, stąd niepozorne Tomaszowe wtrącenie tłumaczące taki sposób mówienia: quasi manifestum $^{37}$. Pytanie nie zdradzają niewiedzy czy wątpliwości Hioba, ale pokorne otwarcie na prawdę ${ }^{38}$.

Dobre stawianie pytań musi iść w parze z właściwym odczytywaniem ducha słów adwersarza. Jednym z zarzutów, które Akwinata podnosi wobec przyjaciół Hioba to właśnie nieliczenie się z duchem tych słów, arbitralne interpretowanie jego twierdzeń, które nie mają nic wspólnego z jego intencją ${ }^{39}$. Niedbałość w tym względzie rzutuje katastrofalnie na drogę prawdy.

Ale forma „dysputy” obejmuje nie tylko formę dialogu Hioba z przyjaciółmi, gdyż cała księga wydaje się dla Akwinaty wielką disputatio nad charakterem opatrzności Bożej ${ }^{40}$. W tym kluczu wyjaśnia poszczególne interwencje i dokonuje ich oceny. A jak w uniwersyteckiej dyspucie, po wymianie poglądów „za” i "przeciw” następuje determinatio magistralis, tak w Księdze Hioba, zauważa św. Tomasz, „ponieważ ludzka mądrość nie wystarcza do pełnego [comprehendendam] zrozumienia prawdy opatrzności Bożej, konieczne było, aby nastąpiło $\mathrm{w}$ tej dyspucie zajęcie stanowiska przez autorytet boski" ${ }^{41}$. Hiob w tej dyspucie o Bogu i jego sprawiedliwości nie pomylił się, podkreśla Akwinata, lecz przesadził w sposobie mówienia - słynny modus loquendi - wzbudzając tym samym u innych wrażenie, że nie zachowuje właściwej czci wobec Boga. A powinien

36 In Iob, cap. 8: „Interrogatio autem generationis pristinae est considerando antiquorum gestorum scripta et ea quae de antiquis per famam feruntur; et quia de rebus antiquis multa fabulose et scribuntur et narrantur".

37 Ciekawą interpretację pytań stawianych przez Jezusa, jej dynamikę manifestacji przedstawia M. Grabowski, Pomazaniec. Przyczynek do chrystologii filozoficznej, W drodze, Poznań 2011.

38 Co widoczne zwłaszcza w kontekście dwunastu stopni pokory: S. Th., II-II, q. 162 a. 4 ad 4.

39 In Iob, cap. 4: „Et primo loquitur Eliphaz Themanites qui verba a Iob proposita non eo animo accepit quo erant dicta...."

40 Wspomina o tym wprost w proœmium komentarza do Psalmów, gdzie dokonuje klasyfikacji różnych stylów i form ksiąg biblijnych.

41 In Iob, cap. 38: „sed quia humana sapientia non sufficit ad veritatem divinae providentiae comprehendendam, necessarium fuit ut praedicta disputatio divina auctoritate determinaretur". 
był wziąć to pod uwagę, że „należy unikać nie tylko zła, lecz także tego, co ma choćby pozór zła" 42 .

Bóg jawi się wprost jako quaestionis determinator, ocenia każdego z uczestników dysputy i wskazuje jak dobry nauczyciel, gdzie pobłądzili: przyjaciele Hioba dokonali niewłaściwych ocen i pobłądzili (zwłaszcza zyskuje reprymendę Boga postawa Eliuda, który niejako wyprzedza swoim przedwczesnym osądem przynależną jedynie Bogu ocenę), w przeciwieństwie do Hioba, który właściwie orzekał o prawdzie opatrzności, lecz w sposób „nieuporządkowany” (inordinato). Bóg zabiera głos $\mathrm{w}$ dyskusji w sposób przypominający turbulencje chmur (aeris turbatione), co w sensie literalnym może przypominać objawienie synajskie czy owe „zagrzmiało”, gdy Bóg Ojciec przemawiał do Chrystusa (J 12,29). Ale może to również oznaczać, stwierdza św. Tomasz, że Bóg przemawia przez wewnętrzne poruszenie w Hiobie, przeżywającym przecież pewne turbulencje duchowe, które łagodzi słowo Bożej mądrości ${ }^{43}$.

\subsection{Pytania Hioba: droga ku pełni poznania: plenius te cognosco}

Śledząc Tomaszowe wyjaśnienia, szybko można zrozumieć, jaki sens przypisuje pytaniom formułowanym przez Hioba. Odpowiedź znajduje się w ostatnich rozdziałach księgi, w których zostaje przedstawione niejako podsumowanie dysputy o opatrzności. Hiob przyznaje, że w swoich słowach nie zachował właściwej czci wobec Bożej wzniosłości i wskazuje na swoją winę. Swoje dotychczasowe zgłębianie Bożej opatrzności opierał na trzech postawach petendo, orando, pulsando i otrzymuje w rezultacie głębsze poznanie samego Boga. Doświadczenia, które na niego przyszły kryły w sobie epifanijną moc: stawiając pytania, choć nieraz może Hiob przekraczał pewne granice (Akwinata określa to wiele mówiącym terminem excesserat) w tej kluczowej dla jego życia dyspucie, to jednak pytając i słuchając odpowiedzi coraz lepiej poznawał Pana. Pytania zmieniały Hioba, obserwuje św. Tomasz, bo go otwierały na odpowiedź owe „wewnętrzne pouczenie” (interius instruendo) - prowadząc w konsekcji od nierozsądnego i przesadnego, pod wpływem zmysłowości i samej ludzkiej logiki, myślenia do nowej jakości poznania Boga. Dawniej było to „znanie ze słyszenia”, teraz Hiob widzi Boga „swoim okiem”. Podsumowuje Tomasz, parafrazując i rozszerzając wypowiedź Hioba: „to znaczy, pełniej Cię znam niż wcześniej, jak ten, kto pewniej poznaje dzięki oczom niż ten, kto tylko słyszy:

42 In Iob, cap. 39: „oportet autem vitare non solum mala sed etiam ea quae habent speciem mali".

43 In Iob, cap. 38. 
dokonał się postęp [duchowy w poznaniu Boga] zarówno dzięki doświadczeniu [percussione], jak i Bożemu Objawieniu"44.

Hiob zostawia w testamencie przekonanie, że droga dojścia do odkrycia tajemnicy cierpienia wiedzie przez pokorę i porzucenie czystej logiki ziemskiej. To dialog z Panem uświadomił mu ostatecznie, że człowiek nie jest kimś odpowiednim [idoneus] do prowadzenia dysputy z Bogiem ${ }^{45}$, choć to sam Bóg zaznacza Tomasz - zachęcał Hioba do dyskusji z sobą. Trzeba jednak to widzieć w szerszej perspektywie, w której zachęta Boga najpierw miała nie tyle czegoś nauczyć Hioba, co przekonać o ograniczoności jego wiedzy. Jak naczynie, które ma zostać napełnione cennym płynem, powinno zostać oczyszczone i opróżnione, aby przyjąć nową jakość ${ }^{46}$. A Hiob przyjmuje słowa Boga z pokorą, dając mu się przekonać, rozumiejąc dzięki pytaniom retorycznym Boga, że jego myślenie ma deficyt rozumienia Bożych spraw: tua ratio deficit a comprehensione divinorum operum ${ }^{47}$.

W charakterystyczny sposób dla swego egzegetycznego stylu Tomasz zatrzymuje się przy tym stwierdzeniu, zdolności do uznania własnego błędu i otwartości na prawdę, a nie na zwycięstwo w szermierce na argumenty, wprowadzając scholastyczną notae. Chodzi o wtrącenie, które zawiesza wywód i uzupełnia go o pewną uwagę o charakterze ogólnym, a przy tym stanowi zebranie myśli lub podsumowanie rozumowania. Zwykle noty zaczynają się od słów notandum est, sciendum est czy considerandum est ${ }^{48}$, co pozwala łatwo je wyobrębnić w strukturze komentarzy. Akwinata zwraca uwagę, że „Hiob przed Bogiem i własnym sumieniem nie tyle przyznaje się do fałszywości swoich wypowiedzi, ani nie oskarża się o próżne intencje, gdyż to, co mówił, wypływało

44 In Iob, cap. 42: „Quare autem sic mutatus sit ostendit subdens auditu auris audivi te, scilicet olim cum insipienter loquerer, nunc autem oculus meus videt te, idest plenius te cognosco quam prius, sicut id quod videtur oculis certius cognoscitur quam quod aure auditur: profecerat enim tum ex percussione tum ex revelatione divina”. W podobnym duchu Akwinata, tytułem podsumowania mowy Elihu, mowi o trzech sposobach, w jakie Bóg rozmawia z człowiekiem: przez światło rozumu naturalnego, przez sny oraz przez trudne doświadczenia (cap. 33).

45 In Iob, cap. 39: „Sed Dominus eum excitat ad considerandum quod homo non est idoneus ad disputandum cum Deo".

46 In Iob., cap. 38: „Interrogatio Dei non est ut addiscat sed ut hominem de sua ignorantia convincat”. Ale co ciekawe Tomasz również i Hioba widzi pragnienie prowadzenia dysputy z Bogiem: dlatego milknie, aby jeśli już zdołał zachęcić kogoś do dysputy - Tomasz posługuje się terminem provocat - zostawić możliwość odpowiedzi.

47 In Iob., cap. 38.

48 Por. T. Gałuszka, Badania nad Biblia w XIII wieku. Super Psalmum XXIII, Homini, Kraków 2005. 
z czystego ducha, lecz [przyznaje się] do lekkości mowy”"49, która jak nieco dalej dopowie Doktor Anielski, mogła dla zewnętrznych słuchaczy tchnąć arrogancją. Hiob przyznaje się do levitas sermonis, a więc niepogłębionego osądu, pozostawania na powierzchni, bez przenikania do sedna sprawy. Porównując $\mathrm{z}$ innymi zastosowaniami levitas $\mathrm{w}$ pismach Akwinaty, może oznaczać także pochopność osądu (widoczną przy grzechach języka ${ }^{50}$ ), czy gdy mowa o levitas mentis nadmierną wiarą w swoje możliwości, która sprowadza na manowce rozumienia, bardziej skłaniając ku chęci górowania „słowem” ${ }^{51}$. Hiob potrafi uznać lekkość swego dyskursu dlatego, że nie prowadził dysputy po to, aby z Bogiem wygrać pojedynek intelektualny: „Hiob chciał dyskutować z Bogiem dla zdobycia wiedzy, jak uczeń z nauczycielem”, zauważa św. Tomasz ${ }^{52}$.

\section{Antropologia „otwarta": sens prób i przeciwności w życiu człowieka}

Od początku swego komentarza Tomasz podkreśla, że przeciwności, które spotykają Hioba, nie są chciane same przez się, ale dzięki odwiecznemu rozporządzeniu Boga są ukierunkowane ad manifestandam virtutem Iob. Tomasz nie utrzymuje, jak później Leibnitz, że Bóg chce, pozytywnym aktem woli, cierpienia będącego niezbędnym warunkiem, ocalić najlepszy z możliwych światów. Optyka Akwinaty jest inna: Bóg bowiem kieruje życiem sprawiedliwych nie tylko ze względu na ich własne dobro, lecz także ze względu na innych. Cierpienie Hioba nie jest też chciane przez Boga ze względu na jakiś inny, wyższy cel: wpisuje się ono w odwieczny plan, ale nie jako „środek do”, gdyż Bóg nie jest źródłem cierpień Hioba: jest nim szatan i jego perwersyjna wola. Bóg dopuszcza cierpienie Hioba, ale ze zdecydowanie innych powodów ${ }^{53}$.

49 In Iob, cap. 38: „Ubi considerandum est quod Iob coram Deo et sua conscientia loquens non de falsitate locutionis aut de superba intentione se accusat, quia ex puritate animi fuerat locutus, sed a levitate sermonis: quia scilicet etiam si non ex superbia animi locutus fuerat, verba tamen eius arrogantiam sapere videbantur".

50 Por. S. Th., II-II, q. 73, a. 3c.

51 S. Th., II-II, q. 164, a. 4, ad 4: „levitas mentis, per quam scilicet homo superbe se habet in verbo".

52 In Iob, cap. 33: „Iob autem cum Deo disputare volebat quasi ad addiscendum sicut discipulus cum magistro".

53 Por. R. Nutt, Providence, s. 9. 


\subsection{Homo dolorosus. Człowiek pośród afflictio}

Dlatego Tomasz uważa za zasadne zatrzymać się przy tym punkcie: jedną sprawą jest trudność pogodzenia tego, co spotyka Hioba, z prawością sądów Boga i Jego opatrznością, czym innym jest - co czynią przyjaciele Hioba - postrzeganie cierpienia Hioba jako bezpośredniego skutku sądu Boga. Życie sprawiedliwego nie ma bowiem jedynie wymiaru "przykładu”, parenetycznej zachęty do dobrych, aby nie upadli, lecz ma także pokazać złym skalę ich „zła”, linię demarkacyjną, która oddziela ich od dobrych oraz uzmysłowić słuszność Bożych wyroków: Sic igitur Deus sanctorum vitam non solum ab electis considerari vult ad profectum salutis sed etiam ab iniquis ad cumulum damnationis, quia ex vita sanctorum condemnabilis ostenditur perversitas impiorum. Widzialność postępowania człowieka sprawiedliwego ma podkreślać i odsyłać do sprawiedliwości sądów Boga.

Zasadniczy temat całej księgi, zdaniem św. Tomasza, oscyluje wokół tej prawdy: przeciwności, które spotykają Hioba nie są per se czy jedynie „karą za grzechy" ${ }^{4}$, lecz ukazują, że jego relacja z Bogiem nie jest motywowana dobrami doczesnymi. Hiob jest typem człowieka wierzącego w opatrzność, dlatego to, co mu się wydarza, przyjmuje $\mathrm{z}$,umiarkowanym smutkiem”, o czym ma świadczyć dla Akwinaty fakt, że nie ulega rozpaczy, zachowuje właściwą miarę, bo dobra doczesne traktuje jako „przypadłościowe” względem tego dobra, które jest substancjalne, wieczne. Ziemskie dobra nie są connaturalis z człowiekiem, a smutek po ich utracie świadczy jedynie o tym, że jego rozum jest poddany naturalnemu porządkowi i kondycji samej natury, która smuci się na skutek utraty jakiegokolwiek dobra. O podobnym „smutku”, zauważa św. Tomasz, można przecież mówić w przypadku Chrystusa, choć była w nim pełnia cnót ${ }^{55}$.

W duchu tej hierarchii dóbr nabierają znaczenia słowa Hioba wypowiedziane w obliczu utraty tego, co wydawało mu się po ziemsku cenne: „Pan dał i Pan zabrał". Kryje się w tych słowach wiara Hioba w to, że także ziemska pomyślność podlega opatrzności, a nie jest dziełem gwiazd czy losu, ale świad-

54 In Iob., cap. 1: „Unde manifestum est quod bona quae agimus non referuntur ad prosperitatem terrenam quasi ad praemium, alias non esset perversa intentio si quis propter prosperitatem temporalem Deo serviret; et similiter e contrario adversitas temporalis non est propria poena peccatorum, de quo fere in toto libro quaestio erit".

55 Smutek Hioba stoi też za przekleństwem dnia swoich narodzin (Hi 3,1), który zostaje przez Tomasza odniesiony do Chrystusa i głębokiego sensu błogosławieństwa tych, którzy się smucą - por. P. Zerafa, Il commento di San Tommaso al libro di Giobbe tra esegesi antica e esegesi contemporánea, Angelicum 71 (1994), s. 461-507. 
czy o Bożej dispensatio ${ }^{56}$. Skąd się bierze jednak ten heroizm Hioba? Akwinata uważa, że ta przykładna zgodność z Bożą opatrznością, która w obliczu utraty dóbr nie neguje jej istnienia ani nie popada w przesadny smutek, wynika z przyjaźni ${ }^{57}$. Hiob jawi się jako przyjaciel Boga, który pragnie tego, co Bóg i dlatego jest $\mathrm{w}$ stanie przyjąć Jego wyroki $\mathrm{z}$ właściwym przyjaciołom zaufaniem, że wyniknie z tego więcej dobrego:

Nie jest bowiem miłe Bogu, że ktoś ma znosić przeciwności, jeśliby nie miało z tego wyniknąć jakieś dobro: stąd choć przeciwność, sama z siebie jest gorzka i sprawia smutek, to jednak rozważana z perspektywy pożytku, który przez Boga jest chciany, winna być radością [...] również i zażywanie gorzkiego lekarstwa, choć ktoś cierpi zmysłowo, to jednak z jakiegoś powodu się cieszy, ze względu na nadzieję wyzdrowienia ${ }^{58}$.

Próba Hioba okazała się daremna dla szatana, ale nie dla Boga. Ukazała Hioba jako głęboko zakorzenionego w cnocie i prawdziwego nauczyciela mądrości, który potrafi wybierać autentyczne dobro. Niemniej jednak cierpienia Hioba są autentyczne i rozwijają się na kilku płaszczyznach: (1) cierpienie fizyczne, ale także (2) cierpienie wynikające z świadomości i wiedzy, że zostało ono dopuszczone tajemniczym zrządzenie, opatrzności, oraz (3) to, które sprawiają w nim żona i przyjaciele, umacniającym w nim poczucie winy. Przezwyciężenie tej afflictio może dokonać się jedynie na bazie właściwej antropologii, która cel ostateczny człowieka nie więzi w immanentnym porządku doczesnej pomyślności, lecz w ostatecznym spełnieniu ludzkich pragnień. Dlatego uwage Akwinaty przykuwają słowa Hioba porównujące życie człowieka do namiotu: przechodniość staje się regułą egzystencji, która jest ukierunkowana przez telos, który zaspakaja definitywnie. A zatem wszystko zyskuje swoje wyjaśnienie z perspektywy celu, punktu dojścia.

Horyzont Tomaszowej refleksji wyznacza swoista inteligibilność teleologiczna, która przyporządkowuje wszystko, co dzieje się w życiu człowieka temu,

56 Por. S. Ausin, La providencia divina en el libro de Job (Estudio sobre la 'Expositio in Iob' de Santo Tomás de Aquino), Scripta Theologica 8 (1976), s. 477-550.

57 Na kluczową rolę „przyjaźni” jako ważnego leitmotif całego systemu Akwinaty, od wątków trynitarnych po intuicje dla życia społeczno-politycznego wskazywał w wielowątkowym studium D. Schwartz, Aquinas on Friendship, s. 53.

58 In Iob., cap. 1: „Non enim esset placitum Deo quod aliquis adversitatem pateretur nisi propter aliquod inde proveniens bonum: unde adversitas, licet ipsa ex se amara sit et tristitiam generet, tamen ex consideratione utilitatis propter quam Deo placet debet esse iocunda, [...]; nam et de sumptione medicinae amarae aliquis ratione gaudet propter spem sanitatis licet sensu turbetur". 
co jest prawdziwym finis ultimus, celem ostatecznym, który nie może zostać zrealizowany w doczesności. Taki jest też sens „namiotu” żołnierskiego, który ma służyć zwycięstwu: jego celowość nie jest w nim samym. Metafora żołnierskiego posłuszeństwa dowódcy i najemnika czekającego na zapłatę w dniu zwycięstwa ukazują sposób działania opatrzności Bożej w życiu człowieka. Zasługuje przy tej okazji na uwage powiązanie, które bazuje na antropologicznej obserwacji Akwinaty dotyczącej „pragnienia”: doczesność charakteryzuje się ciągłym niespełnieniem, niezadowoleniem $\mathrm{z}$ tego, co już się osiągnęło - w przeciwieństwie do celu ostatecznego, który nie popycha ku czemuś innemu ${ }^{59}$. Nie bez znaczenie pozostają tu uczucia:

To zaś wspólne jest wszystkim ludziom żyjącym na ziemi, że więcej i mniej to odczuwają ludzie wedle tego, że bardziej lub mniej doświadczają radości lub smutku: bowiem, gdy ktoś jest radosny mniej pragnie przyszłości, bardziej zaś [pragnie przyszłości] gdy jest pogrążony w smutku ${ }^{60}$.

W takim sensie odczytuje Tomasz zakończenie księgi Hioba, w którym jest mowa o restytucji tego, co Hiob stracił na początku. Czy jest to klasyczny happy end? Akwinata, analizując ostatnie zdania księgi, zauważa, że szczęście Hioba - „drugie szczęście Hioba”, jak pisała Anna Kamieńska - zostaje nie tyle podwojone materialnie, ile jakościowo. Tomasz z Akwinu zwraca uwagę nie tyle na liczbę dzieci, ile na niezwykłe piękno córek Hioba. Bo to jego szczęście nie jest powrotem do poprzedniego stanu, prostym wyrównaniem, lecz szczęściem piękniejszym, jakościowo nowym, choć z blizną cierpienia. Z drugiej strony, św. Tomasz zauważa, że w obfitej liczbie potomków Hioba objawia się również „pełnia życia”, która jest zapowiedzią przyszłej chwały - mocy łaski, która się ujawnia również $\mathrm{w}$ doświadczeniu próby ${ }^{61}$.

59 In Iob., cap. 7: „Manifestum est enim quod quaelibet res adepto ultimo fine quiescit, unde necesse est quod quando voluntas humana ultimum finem consecuta fuerit, in illo quiescat et ulterius ad alia desideranda non moveatur; huius autem contrarium in praesenti vita experimur, nam semper homo quasi non contentus praesentibus futura desiderat: unde manifestum est in hac vita ultimum finem non esse, sed hanc vitam ordinari ad alium finem sicut ordinatur militia ad victoriam et dies mercennarii ad mercedem".

60 In Iob, cap. 7: „Et hoc quidem commune est omni homini viventi super terram, sed plus et minus hoc sentiunt homines secundum quod magis aut minus gaudiis seu tristitiis afficiuntur: nam qui in gaudio est minus desiderat futurum, plus autem qui in tristitia”.

61 Por. K. Numfor, The Hermeneutics of the 'Happy' Ending in Job 42:7-17, De Gruyter, Berlin 2005, s. 64-66. 


\subsection{Adversitas. Człowiek w obliczu zła}

U początku dyskusji Hioba z przyjaciółmi (których rolę sprowadza Akwinata do bycia swoistą ścieżką dostępu, którą wykorzystuje szatan, aby zasmucić - grzesznym i pełnym niewiary smutkiem - Hioba) stoi niewłaściwie zrozumiany przez przyjaciół lament Hioba. Jest to lament, który nie oskarża, ale uzmysławia gorycz, wielkość cierpienia i niewinność Hioba ${ }^{62}$. Wpisuje się tym samym w drugą ratio do powodu doświadczania przeciwności, które dotykają człowieka i mogą nieraz wydawać się nawet „biczowaniem”. W jednej z not komentarza Tomasz wylicza trzy scenariusze obecności cierpienia

Trzeba również zauważyć, że Hiob we wspomnianych słowach dotyka trzech powodów, dlaczego ktoś w tym życiu jest doświadczany [flagellatur] przez Boga: po pierwsze, aby zniknęła jego złośliwość i aby w ten sposób nie mógł wyrządzać szkody innym [...]. Drugi powód to dla wypróbowania człowieka, aby pokazać jest cnotę $[. .$.$] ; po trzecie jako karę za grzechy [\ldots]^{63}$.

Lament jest oznaką zmysłowej natury Hioba, ale poddanej rozumowi. Człowiek dzieli ze zwierzętami zmysłową naturę, a jej właściwością jest to, że wewnętrzne przeciwności wyraża głosem ${ }^{64}$. Lament w ustach Hioba to znak jego natury ${ }^{65}$, a nie dyskursywne zarzuty przeciw Bogu. To raczej ekspresja realizmu sytuacji, która go dotyka ze względu na dobro - przy czym niezwykle znaczące jest w przytoczonym powyżej tekście owo powiązanie „próby” z „manifestacją cnoty", ad probationem ut virtus eius manifestetur.

Warto zwrócić uwagę, że adversitas to termin najczęściej pojawiący się, według Corpus Thomisticum, wśród dzieł Akwinaty właśnie w komentarzu do księgi Hioba, w opozycji do prosperitas, która jest wrodzona człowiekowi jako temu, który ukonstytuował się $\mathrm{w}$ swoim bycie i pozostaje $\mathrm{w}$ relacjach $\mathrm{z}$ inny$\mathrm{mi}^{66}$. Przeciwności pojawiają sie dla sprawiedliwego $\mathrm{z}$ jakiegoś powodu. Szatan próbuje udowodnić, że Hiob jest hipokrytą (simulate), dlatego dotknięcie

62 W. Brueggemann, The Costly Loss of Lament, Journal for the Study of the Old Testament 36 (1986), s. 57-71.

63 In Iob., cap. 7.

64 Por. In Ps., 48, n. 6.

65 Por. J. Yocum, Aquinas's Literal Exposition on Job, w: T. Weinandy, D. Keating, J. Yocum (red.), Aquinas on Scripture. An introduction to His Biblical Commentaries, T\&T Clark, London 2005, s. 32.

66 In Iob, cap. 1: „Principium autem prosperitatis temporalis, post bonam consistentiam personae propriae, consistit in personis coniunctis et praecipue in natis qui sunt quodammodo aliquid parentum". 
przewciwnościami ma to odsłonić: w przypadku udających cnotliwych wystarczy już umiarkowane cierpienie, aby okazało się, że cnota nie zapuściła w nich korzeni ${ }^{67}$. A są to przeciwności, które pojawiają się niespodziewanie, tak, aby Hiob nie mógł ich „oswoić”, bo jak zwraca uwagę Akwinata, jeśli uprzednio zostaną rozpoznane trudności, to łatwiej je znosić. Hioba spotyka nieszczęście w chwili największej radości, gdy na myśl nie przychodzi, że może go spotkać coś złego ${ }^{68}$. Wszystko po to, aby nie tylko pokazać dramat sytuacji, ale absolutność problemu, który się jawi. Problem jest jasny i czytelny.

Poza tym, zauważa św. Tomasz, strategia szatana polega na stopniowym wytrącaniu Hioba z cierpliwości: dlatego stopniuje "dawkę" przeciwności, a minori ad maiora, aby siłą nacisku zmiażdzyć cierpliwość Hioba. Między cierpieniem a cierpieniem nie ma chwili przerwy, sekwencja ma nie pozwolić na odrodzenie się w Hiobie cierpliwości, a rozmiar przeciwności, pochodzących od ludzi i od Boga, jak można byłoby postrzegać, obliczone jest w strategii złego na mentalne „sprowokowanie Hioba” ${ }^{6}$.

Dokonując charakterystycznego dla siebie „rozszczepienia” głównego wątku egzegezy, Tomasz na podstawie jednej z wypowiedzi Elifaza o wcześniejszym postępowaniu Hioba (Hi 4,3: „Tyś przecież wielu pouczał, wzmacniałeś omdlałe ręce, twe słowa krzepiły słabych, umacniałeś chwiejące się kolana”), zwraca uwagę, że w obliczu doświadczonych przeciwności i cierpienia człowiek zachowuje się różnie. To okazja dla Akwinaty, aby pokazać, jakie działanie drugiego człowieka może okazać się pomocne dla tego, kto staje w obliczu cierpienia. Są tacy, po pierwsze, którzy łatwo wpadają w pokusę niecierpliwości nie zdając sobie sprawy, że przeciwności można przekuć na cnotę - jako, że błąd rodzi się z ignoracji, pomocą może okazać się „pouczenie”; inni choć stawiają opór, to jednak ulegają zmęczeniu w dobrym działaniu i tych ręce omdlałe trzeba „wzmacniać”; dla innych przeciwności stają się przyczyną zwątpienia, bo są przekonani, że pochodzą z woli Bożej - tych należy, jak Hiob czynił, „krzepić” słowem; czwarty modus podejścia człowieka do przeciwności wskazuje na tych, którzy są w stanie znieść trudności jedynie, gdy są małe, ale jeśli stają się wiel-

67 In Iob, cap. 1: „Et notandum quod ex magna adversitate etiam vere iustorum interdum corda commoventur, sed simulate iusti ex modica adversitate turbantur velut nullam virtutis radicem habentes".

68 In Iob, cap. 1: „Considerandum est etiam quod ab his quae subito superveniunt hominis animus magis commovetur, nam praecogitata adversa facilius tolerantur; et ideo ut Iob magis commoveretur, in tempore maximae iocunditatis quando minus de adversitate cogitari poterat, ei Satan adversitatem induxit, ut etiam ex ipsa iocunditate praesenti adversitas gravior apparere".

69 In Iob, cap. 1: „Ut quasi eius menti imprimeretur quod non solum ab hominibus sed etiam a Deo persecutionem pateretur, et sic facilius contra Deum provocaretur”. 
kie, wówczas - jak kolana nie mogące już utrzymać ciężaru - uginają się i tych trzeba „umacniać"70.

Zamysł szatana nie powiódł się, cierpienie nie złamało Hioba. Ale to nie oznacza, że to, co spotkało Hioba, było jedynie w służbie uzasadnienia tezy złego, jakoby Hiob był tylko „tłem” dla udowodnienia „czegoś”, jak pionek w grze. Jak już wspominaliśmy, Tomasz z naciskiem powtarza na kartach komentarza, że Bóg nie działa ze względu na zło, lecz dobro: nie chodzi tylko o „przekonanie” Boga, którego wiedza przecież nie potrzebowała tego rodzaju sprawdzianu wierności Hioba, ale chodzi o glorificatio sanctorum et maiorem damnatio Diaboli et impiorum ${ }^{71}$.

\subsection{Człowiek między wiecznością i czasem}

Doświadczenia Hioba odsłaniają także prawdę o człowieku zanurzonym w świecie, który pozostaje wezwany do wieczności poprzez czas ${ }^{72}$. Ale niejako w tle pojawia się kluczowe dla księgi pytanie - zapewne także rozwiązanie problemu Hioba: w jaki sposób oddziałują na siebie życie na ziemi i życie po śmierci. Czy odpowiedź na dramat Hioba jest możliwa z perspektywy immanentnej? Dysputa, jaką jest Księga Hioba zmienia perspektywy, jak reżyser, który nie chce ujęcia tylko z jednego punktu widzenia.

Jak zauważa Eleonore Stump w swej monografii o Akwinacie, panuje wiele nieporozumień co do postrzegania zasadniczego tematu komentarza do księgi Hioba $^{73}$. Tomasz nie prowadzi teodycei, nie pyta czy cierpienie niewinnych jest dowodem na nieistnienie Boga, lecz ukazuje właściwą perspektywę ludzkiego

70 In Iob, cap. 4: „Sunt enim aliqui qui per impatientiam deficiunt ex ignorantia dum nesciunt adversis uti ad virtutem, et quantum ad hos dicit ecce docuisti multos; quidam vero primo quidem in adversis virtuose agunt sed adversitate durante quasi recta actione fatigati deficiunt, et quantum ad hos dicit et manus lassas roborasti, scilicet bonis inductionibus; sunt etiam aliqui qui in adversis in dubitationem incidunt an ex divino iudicio proveniant, et quantum ad hos dicit vacillantes confirmaverunt sermones tui; sunt etiam aliqui qui parvam quidem adversitatem sustinerent sed sub magna adversitate quasi sub magno pondere deficiunt, et quantum ad hos dicit et genua trementia confortasti, scilicet tuis sermonibus: tremunt enim genua homini magnum pondus portanti”.

71 In Iob, cap. 41.

72 C. Smith, The metaphysical presuppositions of being-in-the-World: a confrontation between St. Thomas Aquinas and Martin Heidegger, Continuum, New York 2010.

73 E. Stump, Aquinas, Routledge, New York 2003, s. 469: „Aquinas takes the book of Job to be trying to instill in us the conviction that there is another life after this one, that our happiness lies there rather than here, and that we attain to that happiness only through suffering". 
szczęścia w jej konotacjach temporalnych ${ }^{74}$. Dlatego właściwe ujęcie „kwestii Hioba" prowadzi przez refleksję nad relacją czasu i wieczności, do pełnego rozumienia celowości ludziego życia i natury szczęścia ${ }^{75}$. Otwiera to przed Tomaszem inspirujący namysł nad powiązaniem życia na ziemi (i tego, co się w nim wydarza) z życiem po śmierci, a nade wszystko z samą refleksją nad „czasem” $i$ jego naturą ${ }^{76}$. Podejmuje ten wątek, będąc prowadzonym niejako samym tekstem księgi Hioba, w której odkrywa szereg obrazów wskazujących na sens ludzkiego czasu na ziemi. Klasycznym przykładem jest obraz tkania materiału, który w pracy dzień za dniem, linia za linią, odsłania ukrytą teleologiczność ludzkiego bytu:

Życie człowieka podobne jest do [tkania] materiału: jak ten bowiem, kto zajmuje się tkactwem przędzie nić za nicią, aby stworzyć doskonały materiał, [a kiedy powstanie odcina go], tak życie człowieka dopełnia się przez dodawania dnia do dnia, a kiedy staje się doskonałe, wówczas jest zabierane. A mówi, że dni człowieka upływają szybciej niż powstawanie materiału, ponieważ tkacz odpoczywa podczas swej pracy, a czas życia człowieka upływa ciągle, bez żadnej przerwy ${ }^{77}$.

Owe continuum czasu zasługuje tutaj na uwagę, nie tylko ze względu na uzmysłowienie ciągłości podmiotowej człowieka, ale umożliwia zaistnienie pamięci, która jest rozpięta w czasie (łączy przeszłość i teraźniejszość).

74 C. Leget, Living with God. Thomas Aquinas on the Relation between Life on Earth and 'Life' after Death, Peeters, Louvain 1997.

75 E. Stump, Aquinas on the Sufferings of Job, w: E. Stump (red.), Reasoned Faith, Cornell, Ithaca and London 1993, s. 353: „what Aquinas' interpretation of Job and general account of evil show us, whether we are inclined to accept or reject them, is that our approach to the problem of evil is a consequence of our attitude toward larger issues, such as the nature of human happiness and the goal of human life."

76 Zagadnienie „czasu” interesowało Akwinatę w wielu różnych kontekstach, por. M. Levering, Eternity, History, and Divine Providence, Angelicum 88 (2011), s. 403-423.

77 In Iob, cap. 7: „Vita enim hominis quantum ad aliquid similis est texturae: sicuti enim ille qui texit telam fila filis adiungit ut ad perfectionem telae perveniat, qua perfecta eam succidit, sic ad hoc quod vita hominis perficiatur dies diebus adduntur, cum autem fuerit perfecta tollitur. Ideo tamen dicit quod velocius transeunt dies hominis quam tela succidatur quia in opere telae textor interdum quiescit, sed tempus vitae hominis absque quiete continuo labitur". 


\section{Podsumowanie}

Hiob uczy stawiania pytań, które prowadzą do odkrycia prawdy, a nie hałaśliwie i bezkształtnie oddalają od istoty sprawy. To pytania, które wnikają w sens, eksplorują w tych odcinakach, gdzie puls jest bardziej wyczuwalny. Hiob pyta, bo wierzy. Dlatego Expositio super Iob Tomasza z Akwinu, artykułując jego przesłanie współczesnym językiem, uzmysławia, że życie Hioba to ostrzeżenie przed egzystencją "na niskich tonach”, w której nie rozbrzmiewają wysokie kwestie życia; to przestroga przed życiem zbanalizowanym i powierzchownym, odartym $\mathrm{z}$ umocowania $\mathrm{w}$ wieczności, a skupionym na doraźnym polu odniesień i retrybucji. To afirmacja prawdy o opatrzności, transcendentnego poszerzania (tak właściwego chrześcijaństwu, które przekracza immanentyzm starożytności) refleksji o człowieku, aby nie zadusić go perspektywą doraźności. To refleksja, która wydaje się niezwykle cenna dla obecnego czasu, który cechuje się, jak mówią niektórzy, „kulturą luzowania”78.

Tomaszowe odczytanie tchnie nadzieją, która przenika historię Hioba. Choć styl księgi biblijnej wydaje się odpowiadać formie „dysputy”, do której Tomasz był przyzwyczajony w toku pracy akademickiej, to jednak Akwinata nie sprowadza Hioba do zimnego dyskutanta. Wręcz przeciwnie, ma świadomość, że teologia Hioba płynie z głębin cierpienia, targanego przeciwnościami umysłu, zdanego na próbę odpowiedzi z wnętrza huraganu, który waloryzuje odpowiedzi przyjaciół, wypowiadane spokojnym umysłem niecierpiących ${ }^{79}$. Tu rodzi się ich postawa próżnego pocieszania (vana consolatio), która w gruncie rzeczy jest oskarżeniem Hioba, nieumiejętnością życia w cieniu pytań, choćby najbardziej trudnych. Zamiast zmieniać teorię, zrewidować poglądy, chcą zmieniać Hioba. Okazują się strażnikami „litery”, a pogromcami „ducha”. Znaczące, że przyjaciele Hioba, jak podkreśla Akwinata, są oskrażani przez Boga o „perwersyjne dogmaty” i paradoksalnie potrzebne jest im pośrednictwo Hioba, wierzącego, za nimi, jego niewierzącymi przyjaciółmi. Wychodzi inaczej niż się wydawało. Księga kończy się nie tyle restytucją mienia, ile zdziwieniem - nie pierwszym i nie ostatnim jednak w Piśmie Świętym.

78 Por. J. Sochoń, Religia jako odpowiedź, Fronda, Warszawa, 2008, s. 60-63 („luzowanie", la relève, to termin ukuty przez J. Derridę na oznaczenie kultury, którą nota bene sam współtworzy).

79 In Iob, cap. 13: „quasi dicat: vos quia modo adversitatem non patimini tranquilla mente de Dei iustitia disputatis, sed si super vos veniat tribulatio - quam commotionem Dei nominat eo modo loquendi quo punitio in Scriptura ira Dei nominatur - mens vestra conturbabitur, et praecipue cum in veritate solidata non sit". 
Tomaszowe myślenie teologiczne naznaczone jest szczególnym uwrażliwieniem na cel: to on rozstrzyga o środkach, które trzeba zastosować, aby się do niego zbliżyć. Nie inaczej jest w historii Hioba. Ocena środków ze względu na nie jest zawsze parcjalna, narażona na niepełność, rodzi pytania, które trzeba „donieśćc do celu. Teologia sytuuje się w dynamizmie tego noszenia pytań i oświetlania ich mocą revelatio, która odsłania cel ostateczny człowieka, ale czyni to wcielając niejako w egzystencję, w jej konkretne kształty. Jak z arrasem, który w trakcie wyszywania sprawia wrażenie ciągu bezsensownych spleceń, węzłów, różnokolorowych nitek i dopiero, gdy się go odwróci i odkryje ich „cel”, ów telos - obraz, który się dzięki nim stworzył, wszystko staje się jaśniejsze. 